\title{
Comparison of post-failure strength of micro-cracked marble with Hoek-Brown failure criterion
}

\section{Mikro-Çatlaklı mermerin yenilme-sonrası dayanımının Hoek-Brown yenilme kriteri ile karşılaștırması}

\author{
Yılmaz MAHMUTOĞLU1* ID , Gökhan SSANS² iD \\ 1,2Department of Geological Engineering, Faculty of Mines, Istanbul Technical University, Istanbul, Turkey. \\ yilmazm@itu.edu.tr, sansg@itu.edu.tr
}

\begin{abstract}
Failure criteria of rock mass is the most important base for designing of surface and underground structures. However, behavior of jointed rock mass and its failure criteria are the controversial subjects of rock mechanics. Main reasons for this discussion are problems during or after the geotechnical application. However, some of the experimental and theoretical approaches are often preferred as they are practical, compatible with engineering considerations, and assist in decisionmaking process. On the other hand, the differentiation in the scale of the geosystem, which varies depending on the scale of geotechnical application, building process, and time, means that the failure conditions will also change. It is clear that the Mohr-Coulomb failure criterion, which is widely used in practice, cannot exactly represent discontinuous geo-environments (fractured rock) consisting of joint systems. Since the rock generally has a discontinuous character, it has been researched since the 1970s, and the Hoek-Brown failure criterion, put forth in the 1980s and modified many times until today, is widely accepted in application. Nevertheless, it is known that the empirical parameters used in this failure criteria proposed for different types of rocks are also open to discussion. In this paper, the results of the mechanical tests conducted on the previously-fissured model material, which is physically similar to rock mass are discussed. Marble samples whose grain boundaries were disturbed by cyclic thermal treatment were used as the model material. Post-failure curves of model material obtained from continuous failure state triaxial tests were compared with Hoek-Brown Failure Criteria. In conclusion, it was shown that the failure envelopes representing intergranular failure in the post-failure phase were similar and comparable to the Hoek-Brown Failure Criterion. However, it is found out that the post-failure strength in low confining stress may be lower than that of estimation by the HoekBrown criterion. Experimental studies have also shown that intergranular failure will develop among structural weaknesses in rock masses, and therefore the strength parameters commonly used in practice will depend on the size of geo-application.
\end{abstract}

Keywords: Continuous failure state triaxial test, Hoek-Brown failure criterion, Post-failure, Rock mass.

\section{Introduction}

Research carried out excluding macro structures such as faults and bends demonstrate that the rock mass strength and behaviour is controlled, in short term, by both material and discontinuity properties and therefore current researches focused on this phenomenon. The strength and failure of rock

\section{Öz}

Kaya kütlesinin yenilme kriteri yüzey ve yeraltı yapılarının tasarımında en önemli temeldir. Ancak, çatlaklı kaya kütlesinin davranıșı ve kırılma koșulu günümüzde de kaya mekaniğinin merak edilen konuları arasındadır. Bu tartışmaların esas nedeni jeoteknik uygulamalar sirasında veya sonrasinda karșilașllan problemlerdir. Bu konudaki, deneye dayalı ve teorik yaklaşımlardan bazıları, mühendislik kanaatleri ile uyumlu ve karar verme sürecine yardımcı olmaları nedeniyle sık kullanılmaktadır. Uygulamanın boyutuna bağlı sistem büyüklüğü kavramının öne çıkarıldığı güncel çalışmalar, mevcut yenilme kriterlerinin kuşkuyla sorgulanır olduğuna işaret etmektedir. Pratikte yaygın kullanılan Mohr-Coulomb yenilme kriterinin çok cisimden olușan süreksiz ortamların (çatlaklı kaya) yenilme koșulunu tam olarak temsil edemeyeceği açıktır. Kayanın süreksiz bir ortam karakteri tașıması nedeniyle, 1970'lerden itibaren arayıș içerisine girilmiș, 1980'li yıllarda önerilen ve günümüze kadar birçok kez modifiye edilen HoekBrown yenilme kriteri uygulamada kabullenilmiștir. Ancak, bu yenilme ölçütünde kullanılan ve farklı türden kayalar için önerilen ampirik parametrelerin de tartışmaya açık olduğu bilinmektedir. Makalede, bu gerçekten hareketle, laboratuvar ölçeğinde fiziksel olarak çatlaklı kayaya önceden benzetilen mikro-fissürlü model malzemesi üzerinde sürdürülen mekanik deney sonuçları tartıșlmıstır. Model malzemesi olarak ısıl ișlemle tane sinırları farklı düzeylerde örselenen mermer örnekleri kullanılmıştır. Sürekli yenilme durumunda üç eksenli deneylerden elde edilen yenilme zarfları Mohr-Coulomb ve Hoek-Brown yenilme kriterleriyle karşılaştırılmıştır. Sonuçta, üç eksenli deneylerde yenilme sürecini ve taneler arası doku yenilmesini temsil eden (postfailure) eğrilerin Hoek-Brown yenilme kriteri ile benzer ve klyaslanabilir olduğu ortaya konmuștur. Karșilaștırma sonucunda, düșük çevre gerilmeleri için elde edilen dayanımın Hoek-Brown yenilme kriterinden elde edilenden daha düşük olduğu belirlenmiştir. Deneysel çalışmalardan süreksiz ortamlarda yenilmenin dokuyu oluşturan elemanlar arasında gelişeceği, dolayısıyla pratikte sıkça kullanılan kesme mukavemeti parametrelerinin sistem büyüklüğüne bağlı olacağı görülmüștür.

Anahtar kelimeler: Sürekli yenilme durumunda üç eksenli deney, Hoek-Brown yenilme kriteri, Yenilme-sonrası, Kaya kütlesi.

can be determined by stress, energy and deformation criteria. Generally, strength of discontinuous rock is characterized to be high against compression but low against tension. Under dynamic and repeated stress, the strength parameters of rock masses change as is the case in other solid materials. The rate of deformation is known to have an impact on such cases. Likewise, other factors such as discontinuities, temperature,

${ }^{*}$ Corresponding author/Yazışılan Yazar 
loading duration, saturation, fluid motion affect rock strength and failure modes [1]-[3] and [4].

In practice, strength criterions, commonly used in rock mechanics, are expressed by principal stresses. The classical Mohr-Coulomb failure envelope is defined by a linear line characterized by cohesion $(c)$ and angle of internal friction $(\varphi)$ (Equation 1).

$$
\tau=c+\sigma \tan \varphi
$$

When it is defined by principle stresses;

$$
\sigma_{1}=\frac{2 c \operatorname{Cos} \varphi+\sigma_{3}(1+\operatorname{Sin} \varphi)}{1-\operatorname{Sin} \varphi}
$$

Based on Equations 1 and 2, the ratio of compressive $\left(\sigma_{c}\right)$ to tensile $\left(\sigma_{t}\right)$ strength is as follows;

$$
\frac{\sigma_{c}}{\sigma_{t}}=\frac{1+\operatorname{Sin} \varphi}{1-\operatorname{Sin} \varphi}
$$

If the angle of internal friction $(\varphi)$ is taken as 45 and 60 degrees, the ratio between compressive and tensile strength will be found 5.8 and 13.9 respectively. However, Mahmutoglu [1] has noted this ratio can be higher than 20 in thermally treated marble samples with disturbed grain boundaries.

Hoek et al [5] suggested that the non-linear failure criterion which they put forward in 1980 was based on laboratory experiments. Several modifications [6],[7] and [8], by adjusting parameters according to the rock mass conditions, have been implemented in the past 40 years, for applying this criterion to practical problems. The last generalized version of this criterion for estimation of rock mass strength have been expressed as:

$$
\sigma_{1}=\sigma_{3}+\sigma_{c i}\left(m_{b} \frac{\sigma_{3}}{\sigma_{c i}}+s\right)^{a}
$$

Where $s, m_{b}$ and $a$ are the rock mass material constants, and $\sigma_{1}, \sigma_{3}$ and are the major and minor principal stresses, respectively; $\sigma_{c i}$ is the unconfined compressive strength of intact rock. The $m_{b}$ was introduced as Hoek-Brown constant for the rock mass, $s$ and $a$ are the constants which depend upon the characteristics of rock mass. The original $m_{i}$ value obtained as curve fitting parameters from triaxial testing of intact rock and $m_{b}$ is a reduced value of $\mathrm{mi}$, which accounts for the strength reducing effects of rock mass. Hoek and Brown [5] re-examined the relationships between GSI, $m_{b}, s$ and $a$, and introduced $D$ to account for near surface blast damage and stress relaxation. The last scaling relationships for these parameters were reported as:

$$
\begin{gathered}
m_{b}=m_{i} \cdot \exp [(G S I-100) /(28-14 D)] \\
s=\exp [(G S I-100) /(9-3 D)] \\
a=1 / 2+1 / 6\left(e^{-G S I / 15}-e^{-20 / 3}\right)
\end{gathered}
$$

Where, the material constants for intact rock are donated by $m_{i}$, $s=1$ and $a=0.5$ values are defined as material parameters corresponding to competent rock and $\mathrm{D}$ as the degree of disturbance to which the rock mass has been subjected to blast damage and stress relaxation. The GSI is a system of rock mass characterization that was developed, by [7] and [8], to correlate the failure curve to engineering geological investigations in the site. It was extended to cover folded and tectonically sheared rock masses in a series of papers by [9],[10]-[12], and [13]. Hoek and Brown have pointed out that above equations are valid for rock masses contain of interlocking angular elements in which the process is dominated by sliding and rotating without a real deal of intact rock failure, under confining stresses [14].

Hoek and Brown [6] have been taken into consideration of laboratory triaxial tests for more than 14 intact rocks. They have used the peak strengths ranging from $40 \mathrm{MPa}$ to $580 \mathrm{MPa}$ of rock samples. As a result, they have defined a non-linear criterion based on this review and the $m_{i}$ parameter was derived from best fit linear regression. The coefficient of determination $\left(\mathrm{R}^{2}\right)$ ranged from 0.68 to 0.99 .

Zhao [15] has issued Mohr-Coulomb and Hoek-Brown linear regressions by a series of laboratory tests. He showed that the intact rock strength under dynamic loads can be better represented by the non-linear Hoek-Brown Failure Criterion. Ghazvinian et al [16] also suggested the non-linear HoekBrown provided a better fit than the linear Mohr-Coulomb. Pariseau [17] concluded the non-linear Hoek-Brown envelope gave a significantly better fit (low to high confining pressures) than Mohr-Coulomb envelope.

Eberhardt [18] noted that Hoek [19] recommends, where possible, the Hoek-Brown criterion be applied directly. However, given that many geotechnical design calculations are written for the Mohr-Coulomb Failure Criterion, it is often necessary to calculate equivalent rock mass cohesion, $c$, and friction angle, $\phi$, values from the Hoek-Brown parameters. Moreover, most practitioners have an intuitive feel for the physical meanings of cohesion and friction, which is not the case for $m_{b}, s$ and $a$. The quantitative conversion of HoekBrown to Mohr-Coulomb parameters is done by fitting an average linear relationship to the non-linear Hoek-Brown envelope for a range of minor principal stress values defined by $\sigma_{t}<\sigma_{3}<\sigma_{3 \max }$. Brown warns against applying programs that calculate equivalent Mohr-Coulomb parameters too automatically without thinking clearly about the range of effective normal stress that applies to the case being considered [20]. If high values of $\sigma_{3 \max }$ are used, then the equivalent effective cohesion value may be too high and the equivalent effective friction angle too low.

This study takes as model material with the bonds between grains boundaries previously loosened by thermal expansion in consideration having similar structural properties of rock masses. The strength envelopes representing both failure and post-failure phases of test specimen were obtained from continuous failure state triaxial tests [21] and compared with Hoek-Brown Failure Criterion.

\section{Material and method}

To obtain a test material structurally similar to rock mass, anisotropic thermal expansion of calcite mineral [22],[23]-[25] and [26] was considered (Figure 1).

For this purpose, some of the cylindrical specimens of Carrara Marble with grain sizes varying between 95 and $150 \mu \mathrm{m}$ was kept as an original while others were exposed to a number of thermal cycles each corresponding to 12 hours of heating and cooling durations. The number of heating-cooling cycles were designated as $0,1,2,4,8$ and 16, refer to specimen categories. The original specimens correspond to specimen category 0 
were not exposed to thermal treatment. The maximum temperature (600 $\left.{ }^{\circ} \mathrm{C}\right)$ specimens were exposed to was determined with reference to differential thermal analysis results [2]. The tests were repeated on 2 specimens each corresponding to the same thermal cycles. The results of unconfined compression tests on testing material are given in Table 1 and the stress-strain curves demonstrating also post failure behaviour under uniaxial compression are also shown in Figure 2 .

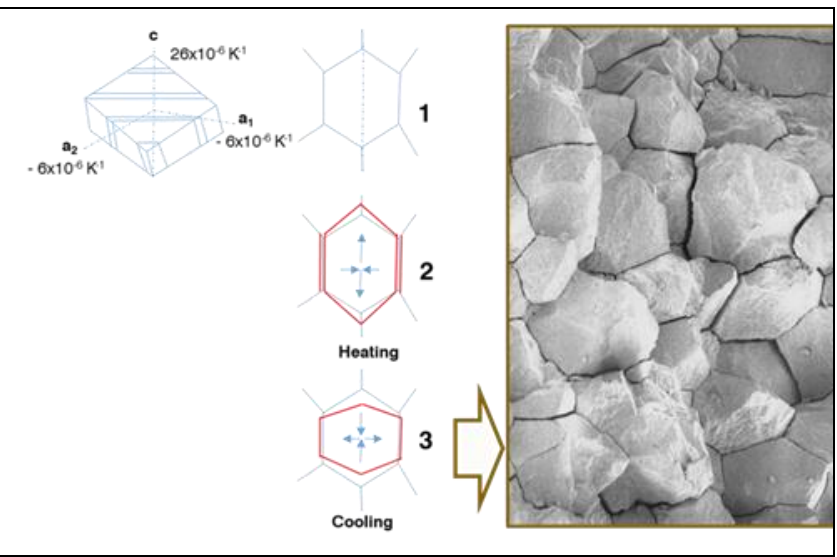

Figure 1. Anisotropic thermal expansion of calcite crystal according to crystallographic axis [25] and micro-fracture along grain boundaries in marble after thermal treatment [24].

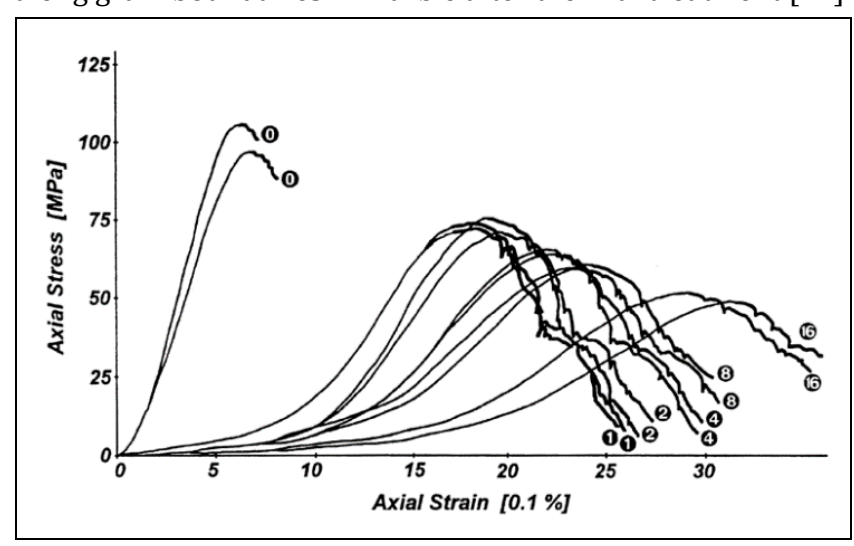

Figure 2. Mechanical behaviour of tested specimen under unconfined compression (The number in circles on the curves show the number of thermal cycles).

Table 1. Compressive strength $\left(\sigma_{c}\right)$, modulus of elasticity $(E)$ and axial strain up to failure $\left(\varepsilon_{1 f}\right)$ of tested specimens.

\begin{tabular}{cccc}
\hline $\begin{array}{c}\text { Specimen } \\
\text { Categories }\end{array}$ & $\sigma_{c}(\mathrm{MPa})$ & $E(\mathrm{GPa})$ & $\varepsilon_{1 f}\left(10^{-3}\right)$ \\
\hline 0 & 105.0 & 22.20 & 6.5 \\
& 97.2 & 25.80 & 7.0 \\
1 & 70.2 & 10.78 & 19.6 \\
& 71.3 & 10.42 & 19.8 \\
2 & 75.0 & 10.27 & 20.2 \\
& 70.5 & 9.15 & 20.3 \\
4 & 65.6 & 7.37 & 22.2 \\
& 63.7 & 7.18 & 22.5 \\
8 & 60.0 & 5.73 & 24.2 \\
& 58.7 & 4.22 & 24.1 \\
16 & 51.2 & 4.10 & 29.5 \\
& 47.1 & 3.77 & 32.2 \\
\hline
\end{tabular}

As it seen from Figure 2 and Table 1, both strength and modulus of elasticity are decreasing after thermal treatment. This was a consequence of the opening of micro-cracks during heating and cooling cycles because of the anisotropic thermal expansion of calcite grains constituting Carrara Marble (Figure 1).

The boundaries of calcite grains in Carrara Marble are irregular, partly curvilinear and planar. Therefore, the material used in experimental study resembles rock mass comprising single lithological type of interlocked blokes with unfilled and irregular discontinuities.

Continuous failure triaxial tests [21] and [27], [28] were repeated on two specimens representing each category to obtain peak and post-failure curves. During the tests, constant axial strain rate was applied as $1.5 .10^{-5} \mathrm{sec}^{-1}$ and a servocontrolled electro-hydraulic pump maintained the confining pressure manually. As for axial loading, a stiff servo-controlled loading machine with an adjustable capacity of $60-3000 \mathrm{kN}$ was used. The soft and pressure-sensitive elastic rubber membrane used in triaxial test was replaced in each test. The stages of tests are depicted with capital letters in Figure 3.

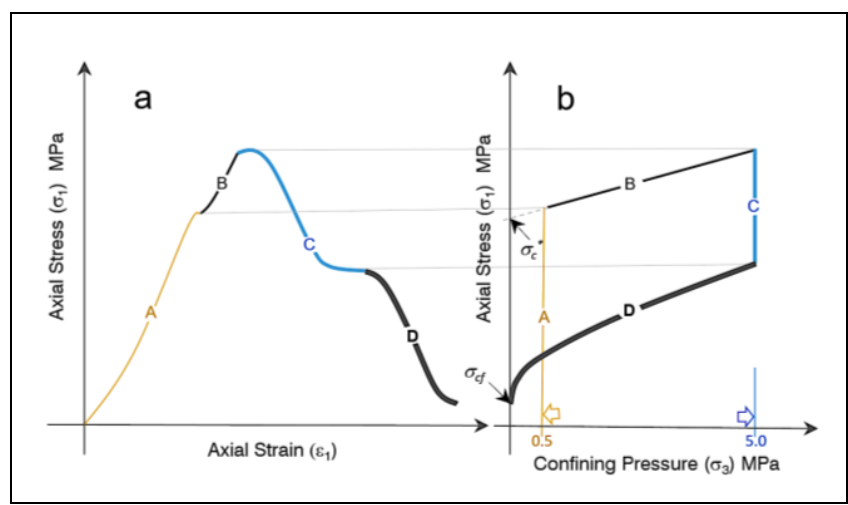

Figure 3. Schematic representation showing the stages of continuous failure state triaxial test.

At first stage, (stage A) constant confining pressure was kept as $\left(\sigma_{3}\right) 0.5 \mathrm{MPa}$ until the beginning of failure. In stage $\mathrm{B}$, it was gradually increased to $5 \mathrm{MPa}$ in a way to linearly increase the axial stress $\left(\sigma_{1}\right)$ in stress-deformation diagram as parallel as to the pre-failure curve. In third stage (C), the specimen was exposed to failure continuously under maximum confining pressure of $5 \mathrm{MPa}$. In other word, the confining pressure was kept constant at its maximum value until the axial stress reached a residual value in the post failure stress-strain curves. At last stage of triaxial test (D), the confining pressure was regularly decreased down to zero. In other words, the envelopes correspond to continuous failure state and postfailure phases were recorded on principal stress plane (Figure 4).

In all tests, the initial confining stress was kept constant as 0.5 MPa. Finally, for each sample, both of the curves corresponding to pre and post failure strength were obtained as graphs on principal stresses plane (Figure $4 \mathrm{~b}$ ).

The tests demonstrated that the failure develops throughout surface similar cone and the calcite grains scattered into powder due to the intergranular failure (Figure 5). 


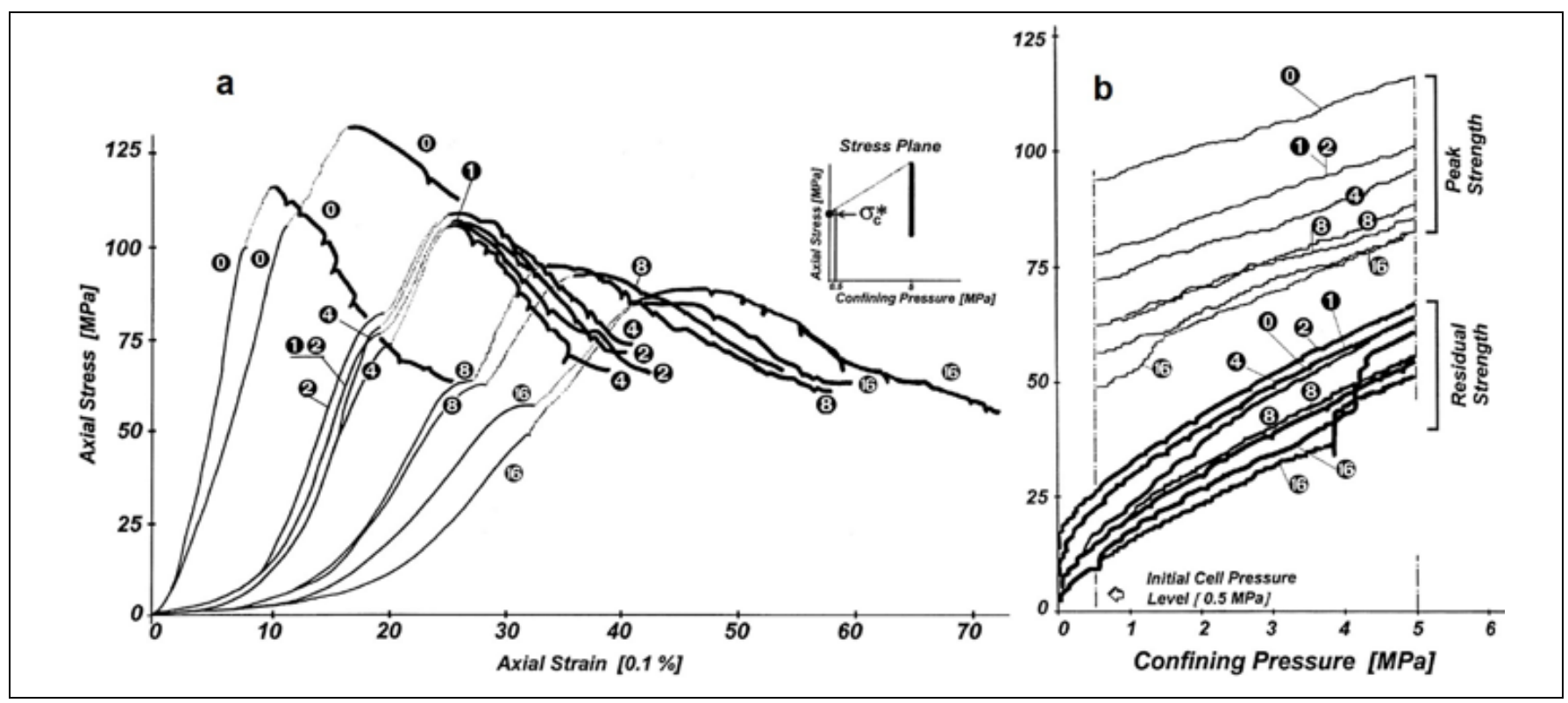

Figure 4. The stress-strain curves obtained from the continuous failure state triaxial tests. (a): and the failure envelopes corresponding to peak and post-failure strengths. (b): of different specimen categories.

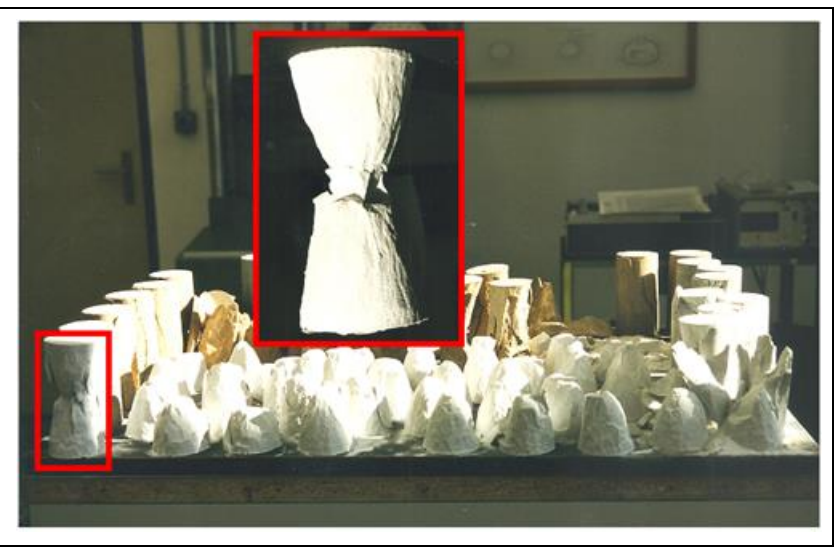

Figure 5. The conical failure surfaces after intergranular failure observed in triaxial tests.

\section{Experimental results}

\subsection{Strength envelope at continuous failure state}

In stress-strain curves in Figure 4a, the first phase of the test until the point of failure is shown with thin and continuous lines. After this point, during in continuous failure state, confining pressure was regularly increased until $5 \mathrm{MPa}$, which is shown with dotted lines. Finally, the thick and dark lines indicate post-failure behaviours. Figure $4 \mathrm{~b}$ shows the envelopes representing continuous failure and post-failure phases. Strength curves of failed specimens obtained during lowering the confining pressure is indicated by thick and dark lines in this figure.

As it shown in Figure 4, the results of triaxial tests generally conform to those obtained in uniaxial tests (Figure 2). The curves demonstrating continues failure states of each specimen are coherent with the level of disturbance, descending downwards by the number of thermal cycles. The peak strength envelops refer to failure (Figure 4b) are almost parallel and indicate a linearity. Therefore, failure envelope of intact rock having micro-fissures can also be explained by Mohr-Coulomb Failure Criteria.

The peak strength parameters $\left(c_{P}, \varphi_{P}\right)$ can be calculated on the basis of Coulomb Failure Criteria (Eq. 8). Continuous failure envelopes appear to be roughly parallel with one another and therefore their gradient $\left(m=\Delta \sigma_{1} / \Delta \sigma_{3}\right)$ can be taken as one same value for all. This demonstrates that, even though the bonds between grains were partly broken down through thermal treatment, there was no significant change in the angle of internal friction, but cohesion decreased by up to $\% 50$.

$$
c_{P}=\sigma_{c}^{*} \cdot \frac{1-\sin \varphi}{2 \cos \varphi} \quad \varphi_{P}=\arcsin \frac{m-1}{m+1}
$$

Where $\sigma_{c}{ }^{*}$ is the point where peak strength envelope intersects the major principal stress axis $\left(\sigma_{1}\right)$, and $c_{P}$ and $\varphi_{P}$ shear strength parameters (Figure 3).

\subsection{Strength envelope of post-failure phase}

On the other hand, the envelopes indicated by dark thick lines in the lower part of Figure $4 \mathrm{~b}$, representing post-failure phase are clearly not linear. These curves have resemblance to the failure envelope put forth in Hoek-Brown Failure Criterion. With this taken into consideration, the post-failure strength curves representing each specimen category are compared below with Hoek-Brown Failure Criterion.

Because of the fact that in Figure $4 \mathrm{~b}$, some of the post-failure strength curves referring to residual strength overlap, therefore one of curve corresponding each sample category was selected and digitized in coherent equations. It is evident that while each envelope representing peak failure strength can be expressed by a simple linear equation, the post-failure strength curves can be expressed well by a multi-term quadratic equation. 
After these comparisons, for all the equations representing residual strength curves of different sample categories, a high coefficient of determination $\left(\mathrm{R}^{2}>0.99\right)$ was found. As is evident from Figure $4 \mathrm{~b}$, the higher the number of thermal cycles is, the more the loss of strength is and the strength curves corresponding to failed specimens generally descend downward. As a main result, it was found out that all of these post-failure strength curves can be defined by following equation;

$$
\sigma_{1}=-a_{f} \sigma_{3}^{2}+m_{f} \sigma_{3}+\sigma_{c f}
$$

Where, the coefficients $a_{f}$ and $m_{f}$ refer to the form of these curves, and $\sigma_{c f}$ corresponds to compressive strength of failed specimen.

The calculated values of $a_{f}$ and $m_{f}$ as well as the ratio of $\sigma_{c} / \sigma_{c}{ }^{*}$ are presented in Table 2 and the correlation between $\sigma_{c f}$ and $\sigma_{c}{ }^{*}$ is also shown in Figure 6.

Likewise, best-fits denoting to the residual strength curves and corresponding failure envelope obtained for the same specimens by using Hoek-Brown Failure Criterion were compared as shown in Figure 7.

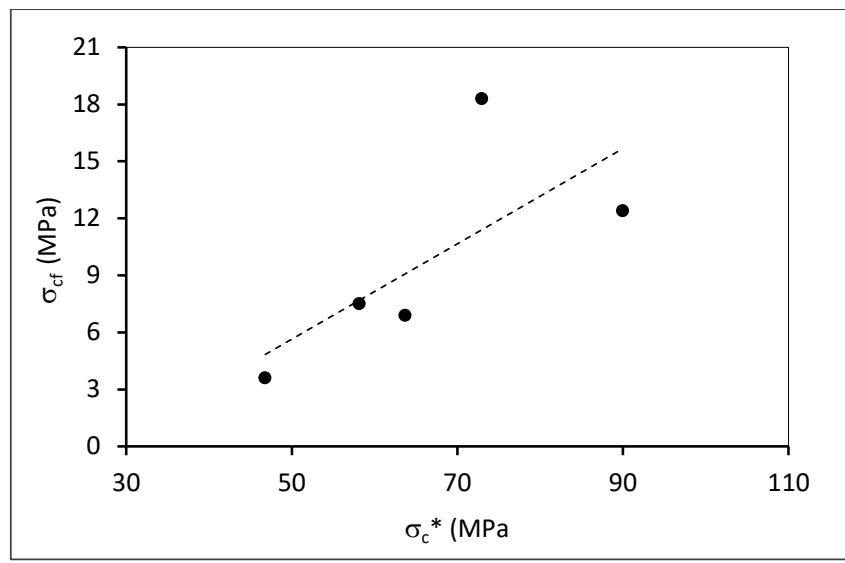

Figure 6. The correlation of peak $\left(\sigma_{c}^{*}\right)$ and residual $\left(\sigma_{c} f\right)$ compressive strengths of specimen categories.

In this figure, thick and continuous lines are the best-fits curves of different specimen categories and the dotted ones (H\&B) show the Hoek-Brown Failure Criterion. The line colours refer to the specimen categories as understood from the figure legend.

For the computations of Hoek-Brown parameters $\left(m_{b}, s, a\right)$ defined according to the Equations 5, 6 and 7, empirical constants for intact marble are taken as $m_{i}=9, s=1$ [29] and $\sigma_{c}=\sigma_{c}{ }^{*}$ into consideration. The comparisons are repeated for four different values of GSI values of 70, 75, 80 and 85 in Figure 7.

As it is clear from this comparison, residual strength curves obtained from continuous failure state triaxial tests do not overlap well with Hoek-Brown strength estimation for rock mass.

Table 2. Empirical constants $a_{f}, m_{f}$ and the compressive strengths of intact $\left(\sigma_{c}{ }^{*}\right)$ and failed $\left(\sigma_{c} f\right)$ specimens.

\begin{tabular}{llllll}
\hline $\begin{array}{l}\text { Specimen } \\
\text { Categories }\end{array}$ & $\mathrm{af}_{\mathrm{f}}$ & $\mathrm{m}_{\mathrm{f}}$ & $\begin{array}{l}\sigma_{\mathrm{c}}{ }^{*}=\sigma_{\mathrm{ci}} \\
(\mathrm{MPa})\end{array}$ & $\begin{array}{l}\sigma_{\mathrm{cf}} \\
(\mathrm{MPa})\end{array}$ & $\sigma_{\mathrm{cf}} / \sigma_{\mathrm{c}}{ }^{*}$ \\
\hline 0 & -1.32 & 16.65 & 90.0 & 12.4 & 0.13 \\
2 & -0.92 & 14.28 & 73.0 & 18.3 & 0.25 \\
4 & -1.23 & 17.43 & 63.7 & 6.9 & 0.11 \\
8 & -0.69 & 12.82 & 58.2 & 7.5 & 0.13 \\
16 & -1.09 & 13.97 & 46.8 & 3.6 & 0.08 \\
\hline
\end{tabular}

In other word, the comparisons demonstrated that the envelopes representing post-failure strength of tested samples do not match but residual strength curves bear similarity with Hoek-Brown Failure Criterion. In addition, estimated strength by this criterion is found to be lower in high confining pressure, but it is higher in low confining pressure (shallow depth) than those derived from continuous failure state triaxial tests.

Strength curves representing post-failure phase (Figure 7) and Equation 9 both clearly show the changes of residual shear strength parameters by confining pressure. Residual friction angles $\left(\varphi_{r}\right)$ and cohesions $\left(c_{r}\right)$ separately calculated by using Equation 8 and values of these parameters corresponding to the same interval of confining pressures are given in Table 3.

Table 3. Residual friction angles $\left(\varphi_{r}\right)$ and cohesions $\left(c_{r}\right)$ obtained for the same confining pressures interval of post-failure strength curves of specimen categories.

\begin{tabular}{|c|c|c|c|c|c|c|c|c|c|c|c|}
\hline \multirow{3}{*}{$\begin{array}{l}\text { Range of Conf. } \\
\text { Pressure } \\
\text { (MPa) }\end{array}$} & \multirow{3}{*}{$\begin{array}{l}\text { Av. } \sigma_{3} \\
(\mathrm{MPa})\end{array}$} & \multicolumn{10}{|c|}{ Specimen Categories } \\
\hline & & \multicolumn{2}{|c|}{0} & \multicolumn{2}{|c|}{2} & \multicolumn{2}{|c|}{4} & \multicolumn{2}{|c|}{8} & \multicolumn{2}{|c|}{16} \\
\hline & & $\begin{array}{c}\varphi_{r} \\
(\underline{\underline{o}}) \\
\end{array}$ & $\begin{array}{c}c_{r} \\
(\mathrm{MPa}) \\
\end{array}$ & $\begin{array}{c}\varphi_{r} \\
(\underline{\underline{o}}) \\
\end{array}$ & $\begin{array}{c}c_{r} \\
(\mathrm{MPa}) \\
\end{array}$ & $\begin{array}{c}\varphi_{r} \\
(\underline{\underline{o}}) \\
\end{array}$ & $\begin{array}{c}c_{r} \\
(\mathrm{MPa})\end{array}$ & $\begin{array}{c}\varphi_{r} \\
(\underline{\underline{o}}) \\
\end{array}$ & $\begin{array}{c}c_{r} \\
(\mathrm{MPa}) \\
\end{array}$ & $\begin{array}{c}\varphi_{r} \\
(\underline{\underline{o}}) \\
\end{array}$ & $\begin{array}{c}c_{r} \\
(\mathrm{MPa}) \\
\end{array}$ \\
\hline $0.0-0.5$ & 0.25 & 75.9 & 1.14 & 63.0 & 1.50 & 68.4 & 0.68 & 65.5 & 0.85 & 61.4 & 0.45 \\
\hline $0.5-1.0$ & 0.75 & 61.4 & 2.30 & 59.3 & 1.71 & 58.2 & 0.95 & 58.2 & 1.07 & 61.4 & 0.46 \\
\hline $1.0-1.5$ & 1.25 & 58.2 & 2.61 & 55.1 & 1.95 & 59.3 & 0.94 & 55.1 & 1.20 & 53.1 & 0.60 \\
\hline $1.5-2.0$ & 1.75 & 53.1 & 3.05 & 56.1 & 1.89 & 60.4 & 0.92 & 56.1 & 1.12 & 54.0 & 0.59 \\
\hline $2.0-2.5$ & 2.25 & 54.0 & 2.97 & 52.2 & 2.13 & 55.1 & 1.06 & 57.1 & 1.10 & 52.2 & 0.62 \\
\hline $2.5-3.0$ & 2.75 & 55.0 & 2.89 & 54.0 & 2.02 & 56.1 & 1.07 & 51.2 & 1.28 & 48.6 & 0.68 \\
\hline $3.0-3.5$ & 3.25 & 51.2 & 3.23 & 54.0 & 2.02 & 52.2 & 1.18 & 50.3 & 1.37 & 52.0 & 0.63 \\
\hline $3.5-4.0$ & 3.75 & 48.6 & 3.46 & 48.6 & 2.35 & 51.2 & 1.18 & 53.1 & 1.26 & 53.1 & 0.60 \\
\hline $4.0-5.0$ & 4.50 & 50.3 & 3.31 & 50.3 & 2.23 & 53.1 & 1.16 & 50.3 & 1.36 & - & \\
\hline
\end{tabular}



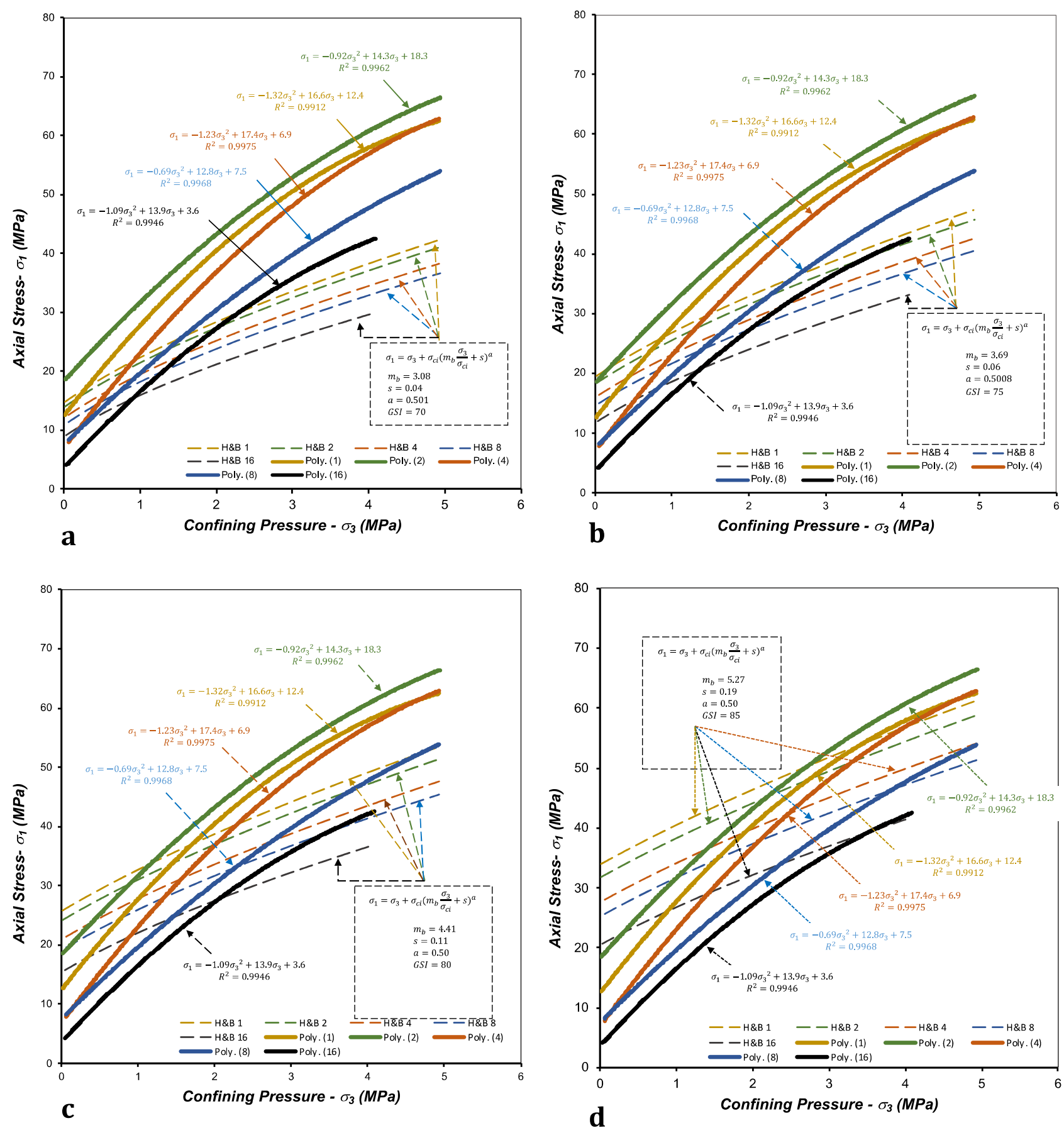

Figure 7. Comparison of post-failure strength curves of specimen categories with Hoek-Brown failure curves for GSI values of 70, 75, 80 and 85 (H\&B and numerical symbol respectively refers to Hoek-Brown failure curves and specimen categories).

In calculation of residual cohesion, residual compressive strength $\left(\sigma_{c f}\right)$ and residual friction angle $\left(\varphi_{r}\right)$ are used instead of $\sigma_{c}{ }^{*}$ and $\varphi_{P}$. It is evident from these values; both of the shear strength parameters depend on confining pressure.

For the description of relationships between residual strength parameters $\left(\varphi_{r}\right.$ and $c_{r}$ ) and confining pressure, they were correlated in Figure 8 and Figure 9 respectively.
As shown in these correlations, it is obvious that both of these relationships can be described well by logarithmic functions. While internal friction angle decreases abruptly by increasing confining pressure, there is a considerable increase in residual cohesion. Although, equations describing the relations are similar for all specimen categories, however, highest coefficients of determination $\left(\mathrm{R}^{2}>0.93\right.$ for internal friction angle and $\mathrm{R}^{2}>0.94$ for cohesion) are obtained for original specimen (Figure 8 ). The lowest values of $\mathrm{R}^{2}$ ( 0.73 for internal 
friction and 0.75 for residual cohesion) are obtained for the specimen which was exposed the highest cycle of thermal treatment.

Figure 8 and Figure 9 both point to changes of shear strength parameters of rock masses $\left(\varphi_{r}\right.$ and $c_{r}$ ) under various confining pressures. For the model material used in this study, they can be confidentially estimated by general forms of below equations;

$\varphi_{\mathrm{r}}=-\mathrm{A}_{\mathrm{f}} \cdot \ln \sigma_{3}+\mathrm{B}_{\mathrm{f}}$

$\mathrm{c}_{\mathrm{r}}=\mathrm{A}_{\mathrm{c}} \cdot \ln \sigma_{3}+\mathrm{B}_{\mathrm{c}}$

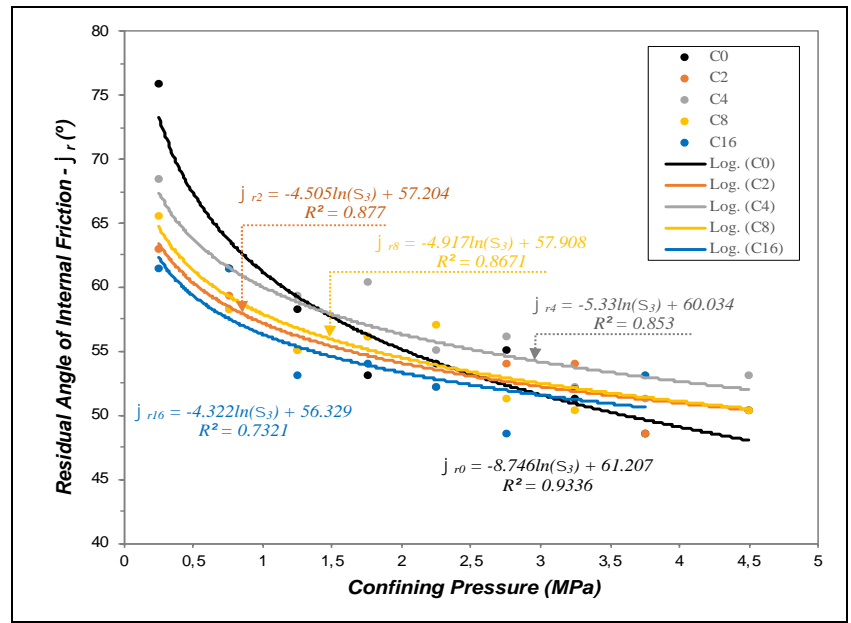

Figure 8. Correlations between residual friction angles $\left(\varphi_{r}\right)$ and confining pressures obtained for the different parts of post-failure strength curves of specimen categories.

Where $A_{f}$ and $B_{f}$ empirical constants for residual internal friction angle and $A_{c}$ and $B_{c}$ for residual cohesion. The ranges of these parameter obtained for each specimen categories are shown on curves in Figure 8 and Figure 9.

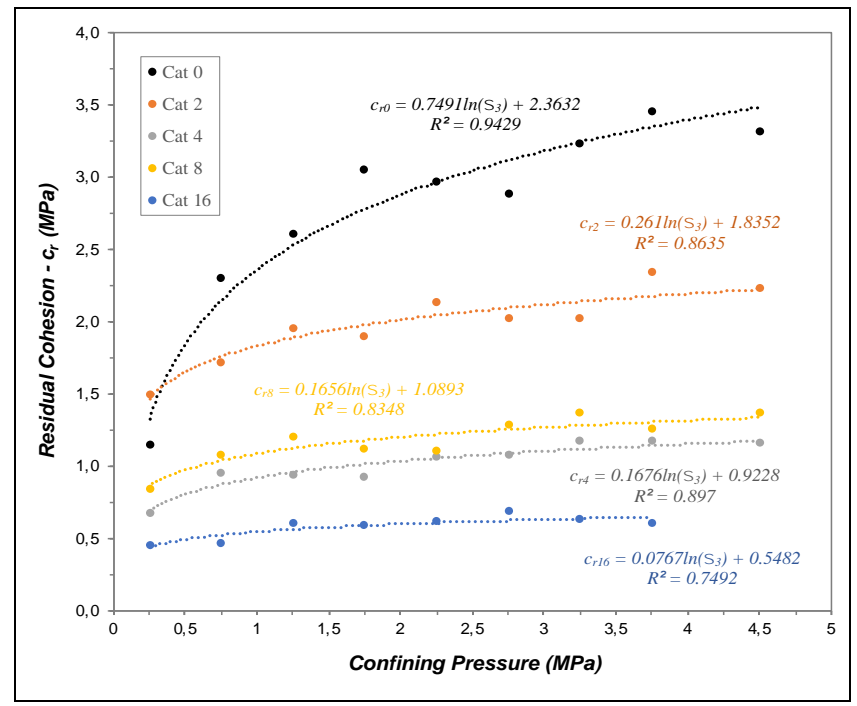

Figure 9. Correlations between residual cohesions $\left(c_{r}\right)$ and confining pressures obtained for the different parts of postfailure strength curves of specimen categories.

\section{Conclusions}

Empirical studies aimed at estimating strength of rock mass have demonstrated that the strengths of intact marble specimen with disturbed grain boundaries can also be explained by Mohr-Coulomb Failure Criterion. The post-failure strength of the same samples, on the other hand, bear resemblance to those put forth in Hoek-Brown Failure Criterion. However, the experimental results do not overlap well with to this criterion. It is found out the strength of brittle rock in shallow depth can be well estimated by a simpler quadratic equation and the residual strength parameters of tested material change considerable by the range of confining pressure applied in this work.

The results of continuous failure state triaxial tests on previously cracked marble have shown that while internal friction angle decreased abruptly by increasing confining pressure, there is a considerable increase in residual cohesion in high confining pressures. In other words, one of the main conclusions of this study is that the internal friction angle of rock masses can be taken probably into consideration as shear strength parameter dominating slope stability. Additionally, failure patterns and the ratio between residual and peak compressive strengths of tested specimens point to physical meaning of intergranular texture of rock masses. Further studies considering the time dependent behaviour of similar model materials would provide a better understanding and shed light on geotechnical applications in rock masses.

\section{Acknowledgement}

Author of this paper, a visiting researcher in ETH Zurich Institute for Geotechnical Engineering, expresses his sincere thanks to the Head of the institute, Prof. K. Kovári for hosting the author and providing financial support to this research.

\section{References}

[1] Mahmutoglu Y. "Mechanical behaviour of cyclically heated fine-grained rocks". Rock Mechanics and Rock Engineering., 31(3), 169-179, 1998.

[2] Mahmutoglu Y. The effects of strain rate and saturation on a micro-cracked marble. Engineering Geology, 82, 137-144, 2006.

[3] Hamdi P, Stead D and Elmo D. "Characterizing the influence of stress-induced microcracks on the laboratory strength and fracture development in brittle rocks using a finite-discrete element method-micro discrete fracture network FDEM- $\mu$ DFN approach". Journal of Rock Mechanics and Geotechnical Engineering, 7(6), 609-625, 2015.

[4] Chen W and Konietzky H. "Simulation of heterogeneity, creep, damage and lifetime for loaded brittle rocks". Tectonophysics, 633, 164-175, 2014.

[5] Hoek E and Brown ET. Underground Excavation in Rock. $1^{\text {st }}$ ed. London, The Institute of Mining and Metallurgy, 1980.

[6] Hoek E, Torres CC, Corkum B. "Hoek-Brown failure criterion" - 2002 Edition. In Proceedings of 5th North American Rock Mechanics Symposium, Toronto, Canada, 7-10 July 2002.

[7] Hoek E. "Strength of rock and rock masses". ISRM News Journal, 2(2), 4-16, 1994. 
[8] Hoek E, Kaiser PK, Bawden WF. Support of Underground Excavations in Hard Rock. Rotterdam, Netherlands, Balkema, 1995.

[9] Hoek E, Marinos P, Benissi M. "Applicability of the geological strength index (GSI) classification for very weak and sheared rock masses. The case of the athens schist formation". Bulletin of Engineering Geology and the Environment, 57(2), 151-160, 1998.

[10] Hoek E and Marinos P. "Predicting tunnel squeezing problems in weak heterogeneous rock masses". Tunnels and Tunnelling International, 132(11), 45-51, 2000.

[11] Marinos P, Hoek E. "GSI: A Geological Friendly Tool for Rock Mass Strength Estimation". Proceedings of the International Conference on Geotechnical and Geological Engineering (GeoEng 2000), Melbourne, Australia, 19-24 November, 2000.

[12] Marinos P, Hoek E. "Estimating the geotechnical properties of heterogeneous rock masses such as flysch". Bulletin of Engineering Geology and the Environment, 60(2), 85-92, 2001.

[13] Marinos V, Carter TG. "Maintaining geological reality in application of GSI for design of engineering structures in rock". Journal of Engineering Geology, 239, 282-297, 2018.

[14] Hoek E, Brown ET. "The Hoek-Brown failure criterion and GSI-2018 edition". Journal of Rock Mechanics and Geotechnical Engineering. 11, 445-463, 2019.

[15] Zhao J. "Applicability of Mohr-Coulomb and Hoek-Brown strength criteria to the dynamic strength of brittle rock". International Journal of Rock Mechanics and Mining Sciences, 37(7), 1115-1121, 2000.

[16] Ghazvinian AH, Fathi A, Moradian ZA. "Failure behavior of marlstone under triaxial compression". International Journal of Rock Mechanics and Mining Sciences, 45(5), 807-814, 2008

[17] Pariseau WG. "Fitting failure criteria to laboratory strength tests". International Journal of Rock Mechanics and Mining Sciences., 44(4), 637-646, 2007.

[18] Eberhardt E. "The Hoek-Brown Failure Criterion". Rock Mechanics and Rock Engineering, 45, 981-988, 2012.

[19] Hoek E. Practical Rock Engineering. e-book, 2007.
[20] Brown ET. "Estimating the mechanical properties of rock masses". Editors: Potvin Y, Carter J, Dyskin A, Jeffrey R., Proceedings of the Firsth Southern Hemisphere International Rock Mechanics Symposium, Australian Centre for Geomechanics, 3-22, Perth: Australian Centre for Geomechanics, Australia, 16-19 September, 2008.

[21] Kovári K, Tisa A, Attinger 0. "The concept of "continuous failure state" triaxial tests". Rock Mechanics and Rock Engineering, 16(2), 117-131, 1983.

[22] Rayleigh Lord. "The bending of marble". Proceedings of Royal Society of London, London, England, 12 May 1934.

[23] Rosengreen KJ, Jaeger JC. "The mechanical properties of an interlocked low-porosity aggregate". Geotechnique, 18, 317-326, 1968.

[24] Carfagni GR. "On the thermal degradation of marble". International Journal of Rock Mechanics and Mining Sciences, 36, 119-126, 1999.

[25] Weiss T, Siegesmund S, Pasolofosaon PNJ. "Ultrasonic wave velocities as a diagnostic tool for quality assessment of marble". Geological Society London Special Publications, 205(1), 149-164, 2002.

[26] Mahmutoglu Y. "Prediction of weathering by thermal degradation of a coarse-grained marble using ultrasonic pulse velocity". Environmental Earth Sciences, 76, 435-455 2017.

[27] Kovári K, Tisa A, Einstein HH, Franklin, JA. "Suggested methods for determining the strength of rock materials in triaxial compression". International Journal of Rock Mechanics and Mining Sciences, Geomechanics Abstracts, 20(20), 283-290, 1983.

[28] ISRM. The Complete ISRM Suggested Methods for Rock Characterization, Testing and Monitoring. 1974-2006. Editors: Ulusay, R. and Hudson JA. Suggested Methods Prepared by the Commission on Testing Methods, International Society for Rock Mechanics, Compilation Arranged by the ISRM Turkish National Group, 159-164, Ankara, Turkey, Kozan, 2007.

[29] Hoek E, Brown ET. "Practical estimates of rock mass strength". International Journal of Rock Mechanics and Mining Sciences and Geomechanics Abstracts, 34(8), 1165-1186, 1997. 